Article

\title{
Spatio-Temporal Variability of the Precipitable Water Vapor over Peru through MODIS and ERA-Interim Time Series
}

\author{
Katherine L. Ccoica-López ${ }^{1}$, Jose J. Pasapera-Gonzales ${ }^{2}$ and Juan C. Jimenez ${ }^{3, * \mathbb{D}}$ \\ 1 Department of Physics, Environmental Engineering and Meteorology, National Agrarian University La \\ Molina, Lima 15024, Peru; k.ccoica29@gmail.com \\ 2 Space Agency of Perú, National Commission for Aerospace Research and Development, CONIDA, \\ Lima 15046, Peru; josephjesus79@gmail.com \\ 3 Image Processing Laboratory, Global Change Unit, University of Valencia, Valencia 46980, Spain \\ * Correspondence: jcjm@uv.es; Tel.: +34-963543781
}

Received: 24 January 2019; Accepted: 4 April 2019; Published: 9 April 2019

\begin{abstract}
Precipitable water vapor (PWV) is a meteorological variable that influences the main processes that occur in the atmosphere. It is not a homogeneous variable, but varies both temporally and spatially according to local conditions. This study analyzes the spatial and temporal variability of the PWV in Peru using MODIS satellite data (MOD05/MYD05 products) during the period 2000 to 2017. MODIS-derived PWV values were complemented with ERA-Interim reanalysis data to take the study period back to 1979. PWV values extracted from MODIS and ERA-Interim were compared against in situ values obtained from five radiosonde stations between the years of 2003 and 2016 (non-continuous data). The study was performed over nine sub-regions of the Peruvian territory: coastal, highland, and jungle sub-regions, which in turn were classified into northern, central and southern regions. The analysis of spatial variability was performed using monthly semivariograms and influencing parameters such as sill and range, whereas the temporal variation was examined by time series of monthly, seasonal, and multi-annual means. The Mann-Kendall test was also applied to determine the presence of trends. The spatial analysis evidenced the heterogeneity of the PWV over the study region, and in most of the sub-regions there was directional variability during the austral summer and austral winter, with the Northeast (NE) and East (E) directions having the greatest spatial variability. The omnidirectional analysis of the sill and range showed that there was a high spatial variability of PWV mainly over the northern and southern jungle, even exceeding the limit area of these sub-regions. The temporal analysis shows that this variability occurs more in the north and center of the jungle and in the north coast, where the content of PWV is higher in relation to other regions, while the central and southern highlands have the lowest values. In addition, the trend test determines that there is a slight increase in PWV for the coast and jungle regions of Peru. Validation analysis using the radiosonde data showed a similar performance of both datasets (MODIS and ERA), with better results for the case of the MODIS product $\left(\mathrm{RMSE}<0.6 \mathrm{~cm}\right.$ and $\mathrm{R}^{2}=0.71$ ).
\end{abstract}

Keywords: precipitable water vapor; MODIS; ERA interim; trend analysis

\section{Introduction}

Water vapour is an atmospheric constituent, and the factor responsible for humidity in the environment and the greenhouse effect [1-5]. Precipitable Water Vapour (PWV) refers to the integration of water vapour along the atmospheric column, and is indicative of the water vapour amount that may be potentially converted to precipitation. PWV is not a homogenous parameter, and it varies according to the geographical and temporal conditions of a given site. PWV follows a latitudinal 
pattern, especially over oceans, where the PWV amount is higher over the Equator and lower over the Poles. However, over continental lands there is a significant influence of the orography, with the lowest values over high altitude sites and locations far away from the sea, and the highest values over low elevation sites and sites near the coast. The PWV also follows a seasonal cycle, with higher values in summer and lower values in winter.

The knowledge of the spatial and temporal variations of PWV are extremely important to produce realistic outputs from climate models [1]. This is especially important for Peru because of the number of microclimates that characterize this country. However, as far as we know, these parameters have been poorly characterized for Peru.

The main objective of this work is to provide a first analysis of the spatio-temporal variability of PWV over Peru in recent decades, covering the period from 1979 to 2017 using reanalysis data, and with focus on recent years (from 2000 to 2017) using high-resolution (1-km) satellite data. Section 2 includes details of the methodology, with a description of the remote sensing and reanalysis datasets, as well as description of the different techniques considered for this analysis. Section 3 presents the results of the spatial and temporal patterns of PWV over Peru, as well as validation results using in situ radiosonde stations. Finally, Section 4 presents the main conclusions drawn from this study.

\section{Methodology}

\subsection{Study Area}

Peru is the third biggest country in South America, and it is located between $0^{\circ}$ and $20^{\circ} \mathrm{S}$. With an extension of $1,285,216.20 \mathrm{~km}^{2}$, it includes three different geographic regions: coast, highlands and jungle. Peru should be characterized by a tropical climate over the entire territory. However, due to different factors such as the presence of the 'Cordillera de Los Andes', the Peruvian flow, the South Pacific anticyclone, and the Amazonian cyclone, among others, Peru is characterized by a number of different climates at regional and also at interregional level.

Because of this diversity of climates, different regions of interest were considered in this study, as illustrated in Figure 1. Hence, three sub-regions (north, central, south) were considered for each of the three main regions (coast, mountains, jungle).

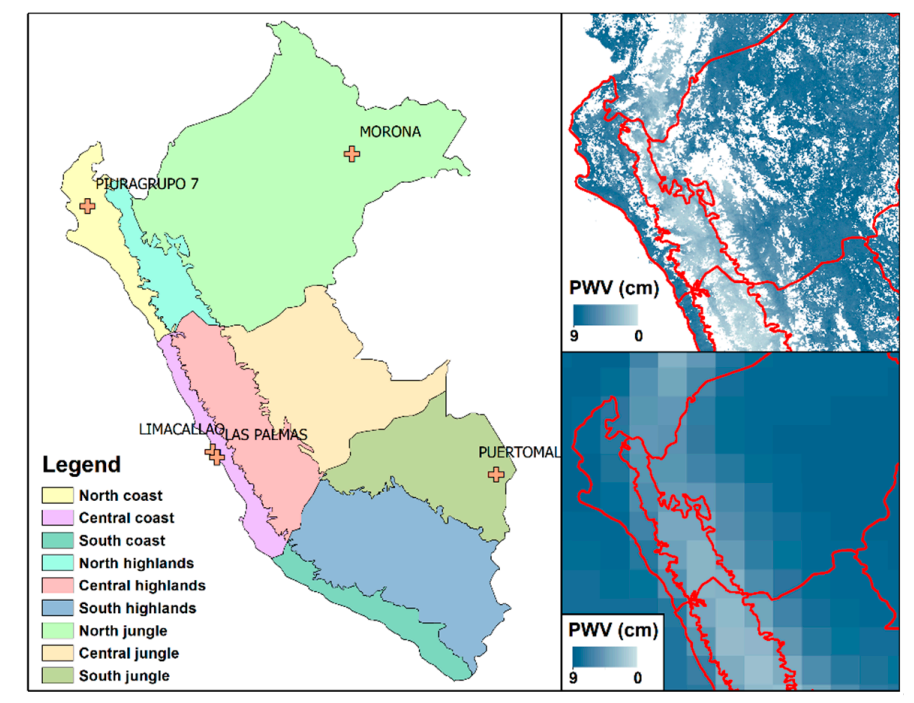

Figure 1. Left: Map of Peru representing the sub regions analyzed in this study: north coast, central coast, south coast, north highlands, central highlands, south highlands, north jungle, central jungle and south jungle. Cross symbols refer to the locations of radiosonde stations described in Table 1. Right: Monthly PWV (arbitrary selection for February-2017) over a Peruvian area obtained from MODIS products at $1 \mathrm{~km}$ spatial resolution (top), and from ERA-Interim products at $0.75^{\circ}$ spatial resolution (79 km approx.) (bottom). 


\subsection{Datasets}

This study combined remote sensing data and reanalysis data to analyse the spatial and temporal patterns of PWV. In situ (radiosonde) data was also used as a reference to test the reliability of remote sensing and reanalysis datasets. Below, we provide a description of the different datasets used in this research.

\subsubsection{MODIS}

The Moderate Resolution Imaging Spectroradiometer (MODIS) is a sensor on board the NASA's Aqua and Terra polar orbiting satellites. Aqua orbits from south to north, passing through the Equator at 1:30 pm (local time), whereas Terra orbits from north to south, passing through the Equator at 10:30 am (local time) [6,7]. The MODIS sensor provides information in 36 spectral bands between $0.4 \mu \mathrm{m}$ and $14.4 \mu \mathrm{m}$ and a spatial resolution of $250 \mathrm{~m}, 500 \mathrm{~m}$ and $1000 \mathrm{~m}$, depending on the spectral band, when combined; MODIS imagery covers the entire earth in one or two days [7-10].

The MODIS project offers products for the atmosphere, land and ocean, of which the MOD05 (from Terra-MODIS) and MYD05 (from Aqua-MODIS) products of PWV were used in this study. This product has a spatial resolution of $1 \mathrm{~km}$ and is based on a split-window algorithm, which calculates the measurement of solar radiation in the near infrared (NIR) over clear areas of the globe [11]. Wavelengths bands of $0.905 \mu \mathrm{m}, 0.936 \mu \mathrm{m}$ and $0.940 \mu \mathrm{m}$, located in water vapor absorption regions, and also wavelengths bands of $0.865 \mu \mathrm{m}$ and $1.24 \mu \mathrm{m}$, located in atmospheric windows, are used by the PWV retrieval algorithm [9,12]. The algorithm is based on a ratio between solar radiation reflected in a water vapor absorption band with solar radiation reflected in a band associated with atmospheric windows (ratio of two channels) or between an absorption band with two atmospheric window bands (ratio of three channels) $[11,13,14]$. However, since MOD05 and MYD05 are based on wavelength channels belonging to the near infrared, the product is sensitive to cloud cover. This, in addition, the uncertainties in surface reflectance and in the spectral response and sensor calibration can lead to an error between $5 \%$ and $10 \%$ in the PWV product $[4,12,14]$.

PWV over Peru was extracted from MOD05 and MYD05 products available at https:/ /ladsweb. modaps.eosdis.nasa.gov. The time period included March 2000 to June 2017 in the case of MOD05, and from April 2002 to June 2017 in the case of MYD05. MODIS products were downloaded in a sinusoidal grid format and re-projected to a geographic lat and lon using the MODIS Conversion Tool Kit. The Quality Assurance band was used to filter out pixels contaminated by clouds or with a low level of confidence. A spatial filter (median filter) was also applied to MODIS imagery to remove anomalous or noisy pixels during satellite acquisition or during imagery mosaicking [15]. MOD05 and MYD05 were averaged to obtain a single daytime MODIS PWV product (except for the period March 2000 to March 2002, when only MOD05 is available).

\subsubsection{ERA-Interim}

Global PWV was extracted from the European Center for Medium-Range Weather Forecasts (ECMWF) ERA-Interim reanalysis (http://apps.ecmwf.int/datasets/data/interim-fulldaily/). The study period of ERA-Interim was from 1979 to 2017.

ERA-Interim is generated through a 4D-Var assimilation scheme [16], which provides a more effective forecast performance than ERA-40, especially in the Southern Hemisphere, even in cases of missing data by one of the sensors used in the assimilation [17]. Its horizontal resolution is T255, $79 \mathrm{~km} \times 79 \mathrm{~km}$ (0.75 degrees), with 60 model levels and 37 pressure levels distributed between the surface and $0.1 \mathrm{~h} \mathrm{~Pa}$, and with a time resolution of 6 hours (0000 UTC, 0600 UTC, 1200 UTC and 1800 UTC) [17-19].

PWV in ERA-Interim is constrained by assimilating clear sky radiation measurements of polar orbiting and geostationary sensors such as TOVS, HIRS, TOMS and SSM/I [20], and it is saved on the model's Gaussian grid (values in $\mathrm{kg} / \mathrm{m}^{2}$ ) [18]. It is important to note that MODIS products are not 
assimilated by ERA-interim. Despite the improvements of ERA-interim over its predecessor (ERA-40), PWV time series extracted from ERA-Interim may show temporary inconsistencies, either due to hardware changes or due to inconsistent processing methods [21]. One of these cases was described by [19], which mentions that there was a negative change in PWV anomalies due to the increase in SSM/I satellite observations from 1992 to 2006. These observations were not treated correctly in ERA-Interim, leading to a decrease in PWV and precipitation values [16].

\subsubsection{Radiosonde}

The PWV extracted from MODIS and ERA-interim was compared against in situ data obtained from radiosonde stations available at the database of the University of Wyoming (http:/ / weather. uwyo.edu/upperair/sounding.html). We used data acquired at 1200 UTC, which is the data available in all the locations, coincides with an ERA-Interim time step and, furthermore, is the closest time to MODIS time acquisitions ( 10:30am for MODIS Terra and $\sim 14: 30 \mathrm{pm}$ for MODIS Aqua). The locations of the radiosonde stations and data period available are detailed in Table 1. Location of radiosonde stations are also included in Figure 1.

Table 1. Name of aerological stations that were used for the verification of MOD05 and ERA-Interim data.

\begin{tabular}{ccccccccc}
\hline \multirow{2}{*}{ Station } & \multirow{2}{*}{ Station Name } & \multirow{2}{*}{ Latitude } & Longitude & \multicolumn{3}{c}{ Time of Measurement } & \multirow{2}{*}{ Data Period } \\
\cline { 6 - 7 } & & & & $\mathbf{0}$ & $\mathbf{6}$ & $\mathbf{1 2}$ & $\mathbf{1 8}$ & \\
\hline 84378 & MORONA & $03^{\circ} 44^{\prime} \mathrm{S}$ & $73^{\circ} 15^{\prime} \mathrm{W}$ & & & $\mathrm{X}$ & & $2003-2010^{*}$ \\
84416 & PIURA GRUPO 7 & $05^{\circ} 11^{\prime} \mathrm{S}$ & $80^{\circ} 36^{\prime} \mathrm{W}$ & & & $\mathrm{X}$ & & $2003-2011^{* *}$ \\
84628 & LIMA/CALLAO & $12^{\circ} 00^{\prime} \mathrm{S}$ & $77^{\circ} 07^{\prime} \mathrm{W}$ & $\mathrm{X}$ & $\mathrm{X}$ & $\mathrm{X}$ & $\mathrm{X}$ & $2009-2010^{*}$ \\
84629 & LAS PALMAS & $12^{\circ} 09^{\prime} \mathrm{S}$ & $77^{\circ} 00^{\prime} \mathrm{W}$ & $\mathrm{X}$ & & $\mathrm{X}$ & $\mathrm{X}$ & $2004-2005^{*}$ \\
& PUERTO & & & & & & & \\
84659 & MALDONADO & $122^{\circ} 38^{\prime} \mathrm{S}$ & $69^{\circ} 14^{\prime} \mathrm{W}$ & & & $\mathrm{X}$ & & $2000-2016^{* * *}$ \\
& BAMAL & & & & & & & \\
\hline
\end{tabular}

* Non-continuous data. ${ }^{* *}$ Non-continuous data and missing data throughout the year $2010 .{ }^{* * *}$ Non-continuous data and missing data throughout the year 2006-2008, 2015.

\subsection{Spatial Analysis}

The spatial pattern of PWV was analysed through the semivariogram, which is a geostatistical tool that allows the characterization of the variability between two spatial points of a given variable, depending on the distance between these two points. Hence, if the variability increases, then a decline of the influence of the PWV at increasingly remote regions is observed [22,23]. Also, it is not necessary to know the mean of the variable for its calculation. The semivariogram describes the PWV variability as a function of the distance between the data points, as expressed in Equation (1):

$$
\gamma(h)=\frac{1}{2 n} \sum_{i=1}^{n}\left\{Y\left(x_{i}\right)-Y\left(x_{i}+h\right)\right\}^{2}
$$

where $Y\left(x_{i}\right)$ is the value of a given parameter at the position $x_{i}, Y\left(x_{i}+h\right)$ is the value of the parameter at the position $x_{i}+h$, and $n$ is the number of pairs of samples separated by a distance $h[24,25]$. Data pairs located at short distances show low values of semivariance; when the distance increases, the semivariance also increases, until it reaches a maximum value named sill. Range is defined as the distance for the sill to be reached, that is, when the semivariogram reaches its limit value, and it represents the distance from which the correlation is negligible [22,24]. Furthermore, there are two types of semivariogram, the first one considers that there is a spatial variation independent of the direction (isotropic behaviour), known as omnidirectional semivariogram; the second type considers the existence of anisotropy, that is, a direction-dependent variability, known as directional variograms $[22,25,26]$. 
For the spatial analysis, variograms of monthly means of PWV obtained from MOD05 and MYD05 products were used (period 2000-2017). To determine the spatial variability as a function of distance using semivariograms, a minimum distance of $1 \mathrm{~km}$ was taken, which is approximately the minimum distance between two adjacent MODIS pixels.

The values of sill and range were determined by adjusting the experimental omnidirectional semivariogram to a spherical semivariogram model, using the ordinary least squares (OLS) method and non-linear regression [26]. The spherical semivariogram is a type of empirical semivariogram model that presents a linear behaviour near the origin and flattens to reach the sill, and it is the only semivariogram model that presents a true sill, and allows easy interpretation of the range value [27]. This model is represented by Equation (2):

$$
\gamma(h)= \begin{cases}c\left(\frac{3 h}{2 a}-\frac{h^{3}}{2 a^{3}}\right) & , \text { for } h<a \\ c & , \text { for } h>a\end{cases}
$$

where $c$ is the sill and $a$ the range of the semivariogram $[27,28]$.

Directional variograms were also obtained for North-South $\left(\mathrm{N}, 0^{\circ}\right)$, Northeast-Southwest $(\mathrm{NE}$, $\left.45^{\circ}\right)$, East-West $\left(\mathrm{E}, 90^{\circ}\right)$ and Northwest-Southeast $\left(\mathrm{NW}, 135^{\circ}\right)$ directions. These variograms were only qualitatively analysed, i.e., values of range and sill were not extracted from the OLS model. In some cases, variograms show a sinusoidal pattern (with peaks and valleys) known as "hole effect". This effect indicates a pseudo-periodic pattern for the given variable (PWV in our case), due to the variation of a high range over a small study area [29]. The range for those variograms characterized by the "hole effect" was obtained as the distance to the maximum of the first peak.

\subsection{Temporal Analysis}

Temporal patterns of PWV were analysed through monthly, seasonal (DJF, MAM, JJA, SON) and yearly means. Statistical indicators were used to determine the seasonal influence, and the Mann-Kendall test was used for trend analysis.

Mann-Kendall is a non-parametric test for the analysis of temporal series regardless of data distribution, missing data, and seasonality [30-32]. The Mann-Kendall test is based on Equation (3):

$$
Z=\left\{\begin{array}{cc}
\frac{S-1}{\sigma_{S}}, & S>0 \\
0, & S=0 \\
\frac{S+1}{\sigma_{S}}, & S<0
\end{array}\right.
$$

where

$$
\begin{aligned}
& \mathrm{S}=\sum_{k=1}^{m} \sum_{j=k+1}^{m} \operatorname{sign}\left(y_{j}-y_{k}\right) \\
& \sigma_{S}=\sqrt{\frac{m(m-1)(m-5)}{18}}
\end{aligned}
$$

with $m$ is the size of the sample and $\left(y_{j}, y_{k}\right)$ the values for years $j$ and $k(j>k)$. Equation (4) represents the Mann-Kendall statistic (S), and measures the trend in the data; a positive (negative) value of $S$ indicates an increasing (decreasing) trend [32,33]. The statistic $S$ is defined by the sign function, which is an indicator function with values of $-1,0$ or 1 , depending on whether $y_{j}-y_{k}$ is less than zero, equal to zero or greater than zero, respectively [33]. Equation (5) defines the variance of $S\left(\sigma_{S}\right)$ when $m \geq 8$ [30]. Correlation is assessed through the Kendall rank correlation coefficient (tau coefficient), obtained as $\tau=S / D$, where $D$ is the maximum permitted value of $S$, given by:

$$
D=\frac{m(m-1)}{2}
$$


The tau coefficient measures the strength of the monotonic association between $y_{j}$ and $y_{k}[32,34]$.

The Mann-Kendall statistical test considers the detection of monotonic trends through the following hypothesis: (i) $\mathrm{H}_{0}$ : variables are independent and equally distributed (no monotonic trend), and (ii) $\mathrm{H}_{1}$ : variables are dependent with a heterogeneous distribution (monotonic trend) [35,36]. The hypothesis $\mathrm{H}_{0}$ is accepted or rejected after calculation of the normalized probability associated to the $\mathrm{Z}$ statistic (see Equation (3)), which is represented by Equation (7) [34]:

$$
f(Z)=\frac{1}{\sqrt{2 \pi}} e^{-\frac{Z^{2}}{2}}
$$

The significance level $(\alpha)$ was fixed to 0.05 (95\% confidence). In this research, the $p$-value associated with this function is compared to the level of significance $\alpha$. If the $p$-value is less than the level of significance $(p<\alpha)$, then the null hypothesis for no trend is rejected $\left(\mathrm{H}_{0}\right)$ and the alternative hypothesis $\left(\mathrm{H}_{1}\right)$ is accepted; otherwise, $\mathrm{H}_{0}$ is accepted.

\section{Results}

\subsection{Spatial Analysis}

The spatial distribution of PWV was analysed through a statistical analysis of the Euclidean distances for each of the study regions to elaborate the variograms (Table 2). Directional variograms were analysed following the directions North-South $\left(\mathrm{N}, 0^{\circ}\right)$, Northeast-Southwest $\left(\mathrm{NE}, 45^{\circ}\right)$, East-West $\left(\mathrm{E}, 90^{\circ}\right)$, and Northwest-Southeast $\left(\mathrm{NW}, 135^{\circ}\right)$, for the seasons December to February (DJF) and June to August (JJA), and taking into account the remarks discussed in Section 2.3.

Table 2. Statistical analysis of distances (in $\mathrm{km}$ ) for the sub-regions of the study area. Values correspond to the minimum (min), percentile 1, median, average distance (mean), percentile 3 and maximum (max) Euclidean distance. Values extracted from MODIS data.

\begin{tabular}{ccccccc}
\hline Subregion & Min & Percentile 1 & Median & Mean & Percentile 3 & Max \\
\hline North Coast & 1 & 90.211 & 161.81 & 190.63 & 268.62 & 631.62 \\
Central Coast & 1 & 101.42 & 229.79 & 262.57 & 396.55 & 755.48 \\
South Coast & 1 & 97.306 & 201.74 & 231.11 & 340.23 & 702.68 \\
North Highland & 1 & 79.321 & 139.15 & 162.36 & 228.14 & 528.11 \\
Central Highland & 1 & 112.871 & 216.15 & 248.93 & 362.56 & 753.94 \\
South Highland & 1 & 148.06 & 237.05 & 256.19 & 347.93 & 751.63 \\
North Jungle & 1 & 219.56 & 345.18 & 360.69 & 482.35 & 1055.12 \\
Central Jungle & 1 & 129.8 & 219.01 & 232.98 & 322.85 & 705.76 \\
South Jungle & 1 & 110.55 & 173.91 & 187.11 & 248.71 & 594.66 \\
\hline
\end{tabular}

Figure 2 shows that for the austral summer period (DJF), most of the sub-regions show a nearly constant variogram in the NW direction $\left(135^{\circ}\right)$, except for the highlands region, where the lines of the variograms do not allow one to visualize a defined sill. The "North Coast" and the "Central Coast" show a greater spatial variability in the East-West direction $\left(\mathrm{E}, 90^{\circ}\right)$, while the other directions present a very similar sill and range. The "South Coast" sub-region shows greater spatial variability in $\mathrm{NE}\left(45^{\circ}\right)$ direction, followed by a high variability in the North direction $\left(0^{\circ}\right)$. The lines of the semivariograms for the N direction over the sub-regions "Central Coast" and "South Coast" are not completed because of the higher value of the distance considered in the analysis compared to the distance in that direction (maximum distance values of $755.48 \mathrm{~km}$ and $702.68 \mathrm{~km}$, respectively; see Table 2).

In the case of the highlands, there are very different directions of variability in each sub-region, but the values of variogram are very low (between $0.15 \mathrm{~cm}^{2}$ and $0.5 \mathrm{~cm}^{2}$ ). In both the Central Highlands and the South Highlands sub-regions, the greatest variability is observed in the NE direction $\left(45^{\circ}\right)$. However, there is also a spatial variability along the North direction for the South Highlands sub-region, very similar to $\mathrm{NE}$, and for the Central Highlands sub-region a high spatial variability in the East $\left(90^{\circ}\right)$ 
direction is also observed. These two sub-regions provide a similar directional pattern of variability than the Central and Southern Coast sub-regions, respectively. The South Highlands, on the other hand, presents a peculiarity during the DJF period, since it does not seem to have anisotropic behaviour; this is because the ranges are approximately similar. In spite of this, as was mentioned before, there is a high variability in the direction NW $\left(135^{\circ}\right)$. In addition, the sill reached lower values along the $\mathrm{N}$ direction compared to the other directions. The jungle showed very high variability values, especially along the $\mathrm{NE}\left(45^{\circ}\right)$ direction for the three jungle sub-regions, and along the $\mathrm{N}$ direction for the Central Jungle and South Jungle sub-regions. In all the three sub-regions, it is difficult to observe a defined sill value and range.
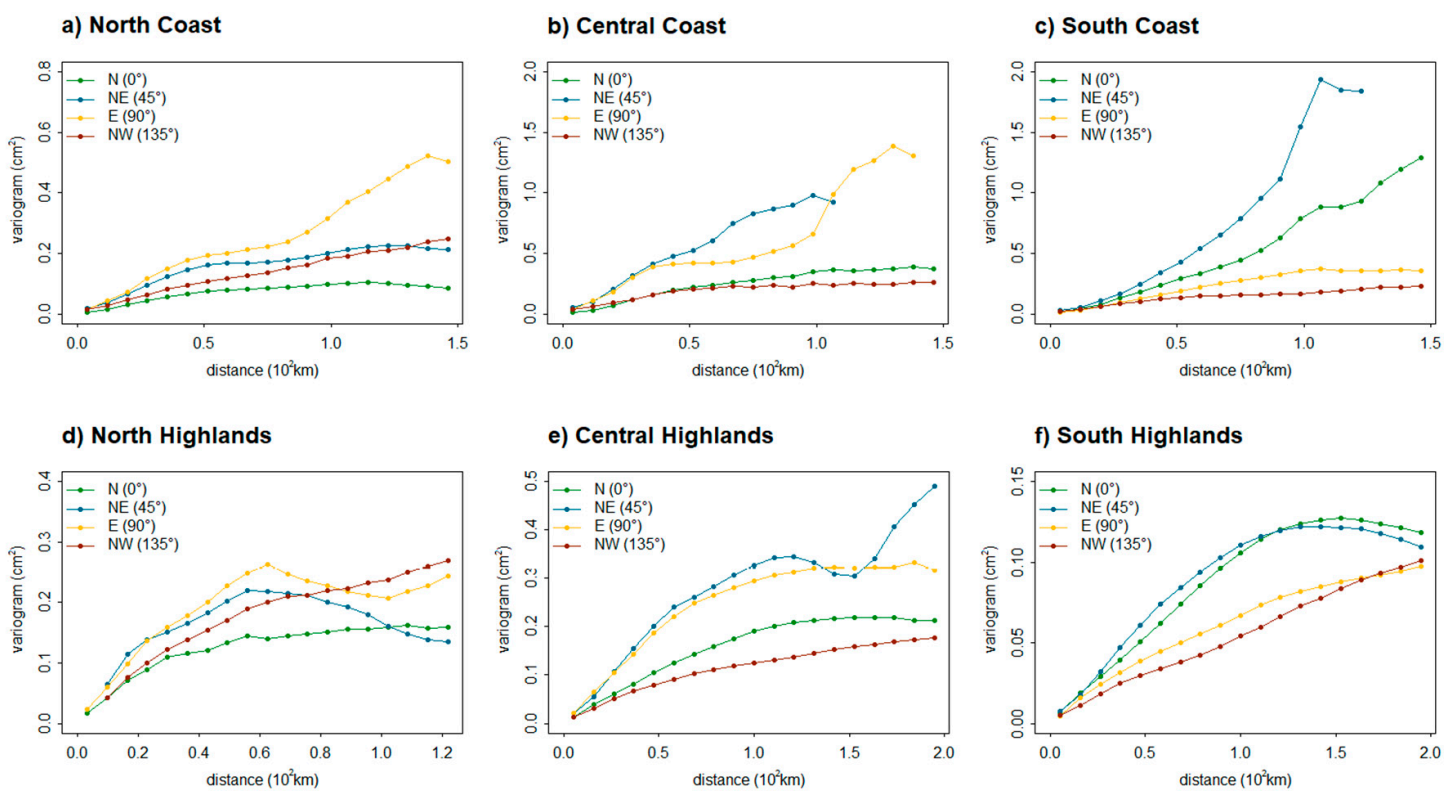

e) Central Highlands

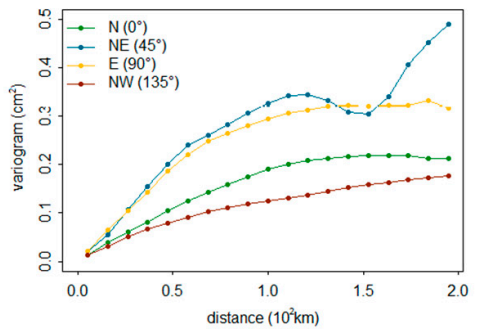

h) Central Jungle

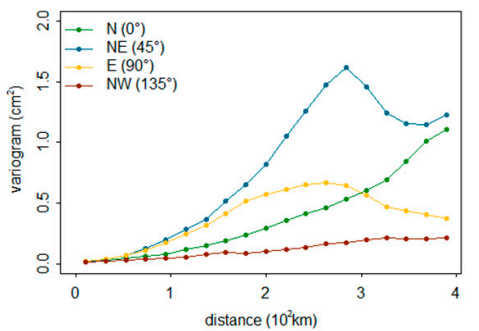

f) South Highlands

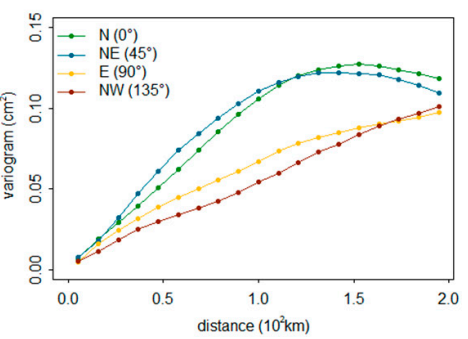

i) South Jungle

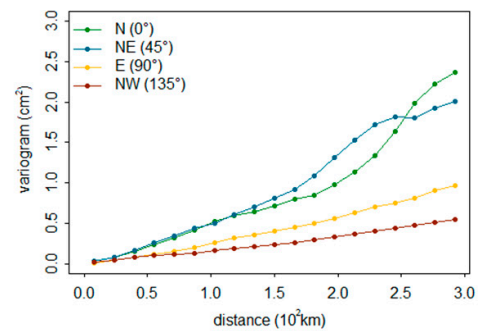

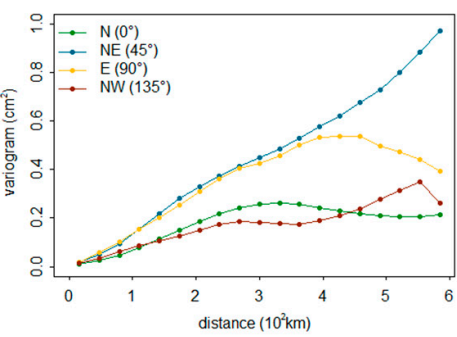

Figure 2. Directional variograms for the different sub-regions of the study area for the DJF season: (a-c) for the Coast region, (d-f) for the Highlands region, and (g-i) for the Jungle region. Values obtained from the MODIS PWV product.

Results obtained for the austral winter period (JJA) are presented in Figure 3. In this case, values of the sill were lower than the values obtained for the austral summer (DJF in Figure 2). For the coast region, the pattern of directional variability is maintained, with $\mathrm{E}\left(90^{\circ}\right)$ and $\mathrm{NE}\left(45^{\circ}\right)$ directions providing the greatest variability. Highlands sub-regions presented a different spatial variability pattern between summer and austral winter. The Northern Highlands sub-region shows a variability increase at short distances $(<60 \mathrm{~km})$ along the $\mathrm{E}$ and NE directions, but a variability decrease from $60 \mathrm{~km}$ to $100 \mathrm{~km}$. However, variability along the NW $\left(135^{\circ}\right)$ direction shows a sustained increase. The Central Highlands sub-region shows a greater variability along $\mathrm{E}$ and NE directions than the northern sub-region, whereas the South Highlands sub-region provides the highest values of variability for the $\mathrm{N}$ and $\mathrm{NE}$ directions. Overall, the jungle sub-regions presented high values of variability without a defined sill, with the greatest variability also along the $\mathrm{N}$ and $\mathrm{NE}$ directions. 
a) North Coast

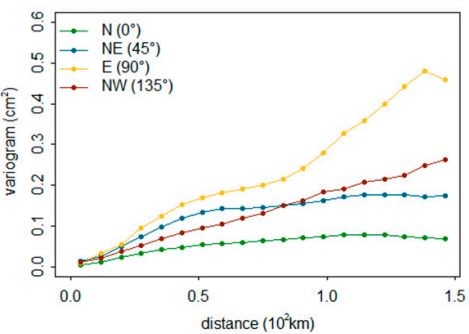

d) North Highlands

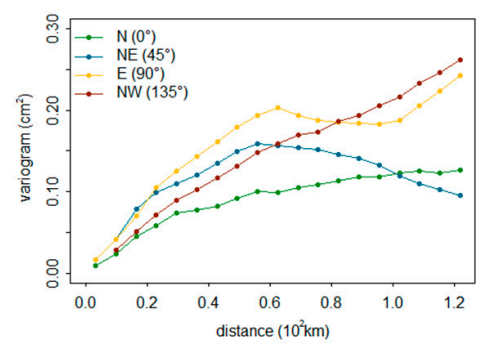

g) North Jungle

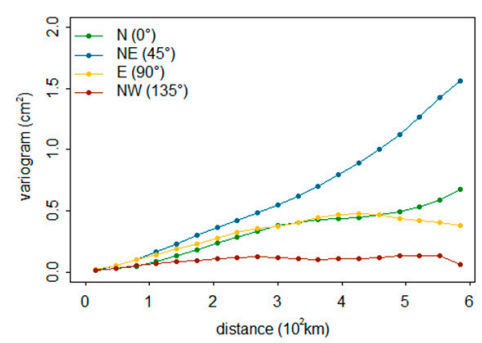

b) Central Coast

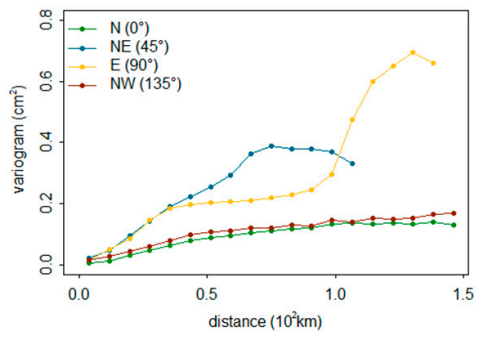

e) Central Highlands

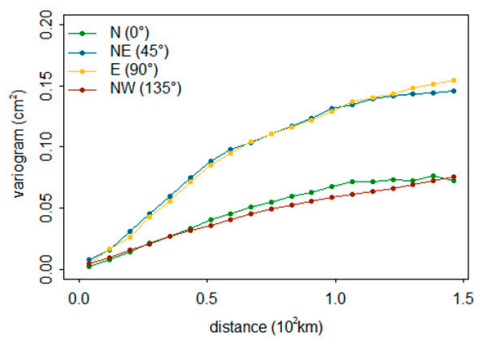

h) Central Jungle

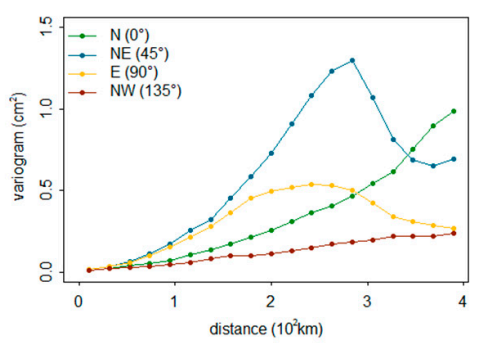

c) South Coast

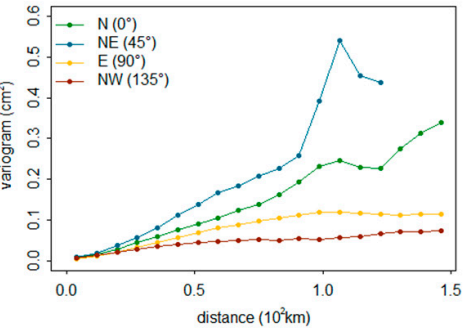

f) South Highlands

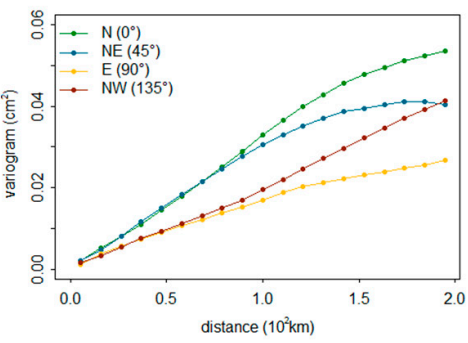

i) South Jungle

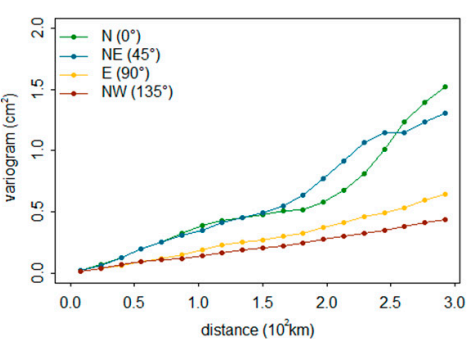

Figure 3. Same as Figure 2, for the JJA season.

Therefore, the spatial analysis for DJF (Figure 2) and JJA (Figure 3) evidences that the highest variability is obtained along the NE and E directions, and in some cases, along the North direction. It should be noted that these directions along the Peruvian territory includes shorter distances, but the highest altitudinal variations. This fact could explain the rapid change in PWV without reaching a steady state. The lowest variability of PWV are typically obtained along the NW direction, where distances are higher and the interregional variations in altitude are not as significant as those observed along the NE direction.

In order to better understand the variability of the PWV as well as the distance at which this variability stabilizes (referred as to radius of the influence area), values for the sill (maximum semi-variance) and range for each study region and month were obtained through the adjustment of omnidirectional variograms by means of the minimal square (OLS) method (as explained in Section 2.3). Results of sill are presented in Table 3. According to the results, it can be observed that there is greater spatial variability in the regions of South Coast during the austral summer months, North Jungle during the austral winter months, and South Jungle during the autumn and austral spring months, the latter showing high variability values for the whole year. In contrast, the lowest sill values were found for the North Coast sub-region during the austral summer and early fall months, and for the South Highlands sub-region during the late fall and austral winter months. Low values of sill were also found during the summer and austral autumn for the South Highlands sub-region. This result suggests that PWV is highly variable between different locations within the southern region of the jungle, whereas the spatial distribution of PWV is more homogeneous over the southern highlands sub-region. 
Table 3. Sill values $\left(\right.$ in $\mathrm{cm}^{2}$ ) for the omnidirectional semivariogram analysis for each sub-region. Values obtained from the MODIS PWV product.

\begin{tabular}{cccccccccc}
\hline Month & $\begin{array}{c}\text { North } \\
\text { Coast }\end{array}$ & $\begin{array}{c}\text { Central } \\
\text { Coast }\end{array}$ & $\begin{array}{c}\text { South } \\
\text { Coast }\end{array}$ & $\begin{array}{c}\text { North } \\
\text { High }\end{array}$ & $\begin{array}{c}\text { Central } \\
\text { High }\end{array}$ & $\begin{array}{c}\text { South } \\
\text { High }\end{array}$ & $\begin{array}{c}\text { North } \\
\text { Jungle }\end{array}$ & $\begin{array}{c}\text { Central } \\
\text { Jungle }\end{array}$ & $\begin{array}{c}\text { South } \\
\text { Jungle }\end{array}$ \\
\hline Jan & 0.111 & 0.425 & 1.562 & 0.140 & 0.215 & 0.122 & 0.220 & 0.462 & 1.317 \\
Feb & 0.098 & 0.524 & 1.886 & 0.158 & 0.252 & 0.131 & 0.255 & 0.469 & 1.364 \\
Mar & 0.105 & 0.500 & 1.417 & 0.179 & 0.279 & 0.124 & 0.284 & 0.528 & 1.215 \\
Apr & 0.085 & 0.335 & 0.768 & 0.178 & 0.213 & 0.091 & 0.405 & 0.509 & 1.084 \\
May & 0.080 & 0.222 & 0.494 & 0.148 & 0.117 & 0.078 & 0.563 & 0.475 & 1.064 \\
Jun & 0.081 & 0.161 & 0.352 & 0.120 & 0.140 & 0.059 & 0.944 & 0.443 & 0.976 \\
Jul & 0.160 & 0.130 & 0.252 & 0.102 & 0.114 & 0.077 & 1.183 & 0.386 & 0.827 \\
Aug & 0.175 & 0.109 & 0.229 & 0.103 & 0.120 & 0.090 & 0.908 & 0.371 & 0.753 \\
Sep & 0.069 & 0.095 & 0.252 & 0.113 & 0.090 & 0.100 & 0.410 & 0.413 & 1.009 \\
Oct & 0.126 & 0.101 & 0.293 & 0.113 & 0.111 & 0.130 & 0.322 & 0.427 & 1.311 \\
Nov & 0.129 & 0.130 & 0.408 & 0.102 & 0.127 & 0.123 & 0.315 & 0.477 & 1.435 \\
Dec & 0.078 & 0.241 & 0.762 & 0.121 & 0.176 & 0.116 & 0.235 & 0.471 & 1.509 \\
\hline
\end{tabular}

It is also important to remark that regions of greater spatial variability show a kind of annual cycle. The South Coast sub-region evidences a cycle with high values in the austral summer and a decline throughout the year. The North Jungle sub-region shows a cycle with the highest values during the austral winter, and the South Jungle sub-region shows a cycle with the highest values of spatial variability during the summer months and the lowest values during the winter months.

Values of range are provided in Table 4. The radius of the influence area for PWV over the North Jungle sub-region was higher during the austral autumn and winter, and over the South Jungle sub-region during the spring and austral summer. However, both regions presented high values throughout the year. In contrast, the lowest range values were obtained for the "North Highlands" sub-region throughout the year, suggesting a lower area of influence for the spatial variability of PWV, followed by the "North Coast" sub-region which showed low range values between December and August, and "Central Coast" that showed low values during the austral spring. The high values shown in the north and south jungle sub-regions indicated that the range was enormous compared to the maximum Euclidean distance of this region (see Table 2). This result implies that PWV does not stabilize in these sub-regions during these months.

Table 4. Range values (in $\mathrm{km}$ ) for the omnidirectional semivariogram analysis for each sub-region.

Values obtained from the MODIS PWV product.

\begin{tabular}{cccccccccc}
\hline Month & $\begin{array}{c}\text { North } \\
\text { Coast }\end{array}$ & $\begin{array}{c}\text { Central } \\
\text { Coast }\end{array}$ & $\begin{array}{c}\text { South } \\
\text { Coast }\end{array}$ & $\begin{array}{c}\text { North } \\
\text { High }\end{array}$ & $\begin{array}{c}\text { Central } \\
\text { High }\end{array}$ & $\begin{array}{c}\text { South } \\
\text { High }\end{array}$ & $\begin{array}{c}\text { North } \\
\text { Jungle }\end{array}$ & $\begin{array}{c}\text { Central } \\
\text { Jungle }\end{array}$ & $\begin{array}{c}\text { South } \\
\text { Jungle }\end{array}$ \\
\hline Jan & 113.32 & 160.03 & 297.20 & 72.65 & 161.11 & 157.45 & 370.36 & 353.91 & 609.95 \\
Feb & 99.19 & 167.56 & 290.69 & 73.64 & 160.80 & 147.61 & 391.06 & 357.83 & 631.17 \\
Mar & 103.81 & 158.52 & 243.36 & 77.84 & 160.04 & 144.57 & 441.14 & 358.44 & 558.22 \\
Apr & 99.50 & 135.80 & 214.28 & 82.82 & 151.68 & 164.15 & 573.51 & 348.10 & 536.77 \\
May & 100.11 & 117.22 & 197.60 & 90.25 & 149.26 & 248.77 & 767.77 & 356.65 & 558.39 \\
Jun & 109.35 & 120.82 & 192.84 & 106.25 & 550.74 & 259.72 & 1317.23 & 346.71 & 567.92 \\
Jul & 107.50 & 125.35 & 184.95 & 104.30 & 546.01 & 538.01 & 1651.82 & 344.92 & 564.77 \\
Aug & 109.23 & 121.16 & 191.31 & 98.68 & 549.07 & 532.12 & 1381.74 & 340.84 & 572.13 \\
Sep & 120.35 & 106.15 & 194.83 & 91.37 & 145.50 & 315.74 & 692.41 & 346.22 & 611.19 \\
Oct & 118.04 & 101.69 & 199.64 & 78.32 & 150.35 & 323.78 & 529.89 & 353.19 & 672.07 \\
Nov & 120.77 & 113.86 & 208.06 & 71.99 & 157.46 & 266.31 & 476.24 & 358.38 & 693.17 \\
Dec & 98.84 & 133.96 & 243.24 & 77.86 & 156.24 & 197.15 & 385.12 & 360.31 & 672.36 \\
\hline
\end{tabular}

These high values for the spatial variability of PWV, and the high distances of variability in the north and south jungle sub-regions are related to the rainfall regimes presented in these regions. The jungle region includes the Amazon rainforest with a high rainfall content acting as a moisture 
sink [37]. The PWV content in the Amazon is usually high and the precipitation regime is different depending on the region [38,39]. Because the Peruvian jungle is part of the central Amazon, it presents high values of precipitation between the months of spring and austral autumn, while the northern region of the Amazon presents high values of precipitation in the austral winter months $[38,40]$.

\subsection{Temporal Analysis}

Temporal patterns at monthly level are shown in Figure 4. The highest values of PWV over all the study regions are obtained from January to May, or even during June in the case of the jungle sub-regions. The lowest values of PWV are observed in July and August. In terms of study regions, northern areas (coast, highland, jungle) showed higher values of PWV compared to Central and South Peru, with northern jungle and northern coast sub-regions providing the highest values of PWV, between $4 \mathrm{~cm}$ and $6 \mathrm{~cm}$. In the case of the northern highland region, PWV values were between 2 and $3 \mathrm{~cm}$. The lowest values of PWV were obtained over the southern regions, especially over the southern highland region, with PWV values below $2 \mathrm{~cm}$. Interregional variations of PWV were also different for each of the study regions. Hence, PWV values over the coastal region (Figure $4 \mathrm{a}$ ) were $4-5 \mathrm{~cm}, 2-4 \mathrm{~cm}$, and $1-3 \mathrm{~cm}$ for the north, central and south sub-zones, respectively. In the case of the highland region (Figure 4c), the northern sub-regions provided PWV values between $2 \mathrm{~cm}$ and $3 \mathrm{~cm}$, but central and south sub-regions provided similar PWV values, below $2 \mathrm{~cm}$. However, the jungle region (Figure 4e) provided similar PWV values (between 4 and $6 \mathrm{~cm}$ ) for each sub-region. Analysis of the standard deviation of PWV (Figure $4 \mathrm{~b}, \mathrm{~d}, \mathrm{f}$ ) do not show significant features, although a difference between sub-regions is observed for the Highlands region, with a smooth seasonal cycle and the Highlands North sub-regions providing the highest values of standard deviation (between 0.7 and $0.9 \mathrm{~cm}$ ).

In agreement with the monthly analysis, the seasonal analysis presented in Figure 5 evidenced again the highest PWV values over the North during the austral autumn (MAM), whereas over Central and South Peru, the highest PWV values are obtained during austral summer (DJF). The lowest PWV values are obtained over the entire continent during austral winter (JJA). These results are also corroborated by the seasonal spatial patterns of PWV included in Figure 6.

The multiannual variability of PWV is analysed in Figure 7, which shows a comparison between the data obtained from ERA-Interim (1979-2017) and the data obtained from MODIS (2000-2017). Both on the Coast and in the Peruvian jungle, it is observed that ERA-Interim provides lower PWV values than MODIS (but values are similar for the case of the Highlands region), with a difference of around $0.5 \mathrm{~cm}$. This discrepancy agrees with previous analysis [19], but it may be also due to the different spatial resolution between the two datasets. In terms of multiannual variability, different peaks of PWV can be observed in Figure 7, especially over the northern coast. The most significant peaks of PWV are observed in 1983, 1997, and 2015, and they are related to the occurrence of the strongest El Niño events in recent decades [41]. The long-term increase of PWV is more evident in the Peruvian coast and jungle regions, whereas significant interannual variations over the highland region are not observed. Changes in the spatial pattern of PWV from the 2000-2017 period are shown in Figure 8, where an overall long-term increase in PWV is observed. 
a) Monthly variation: Coast

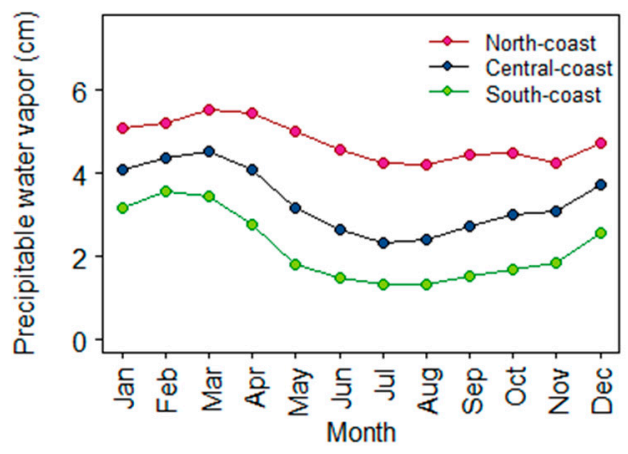

c) Monthly variation: Highlands

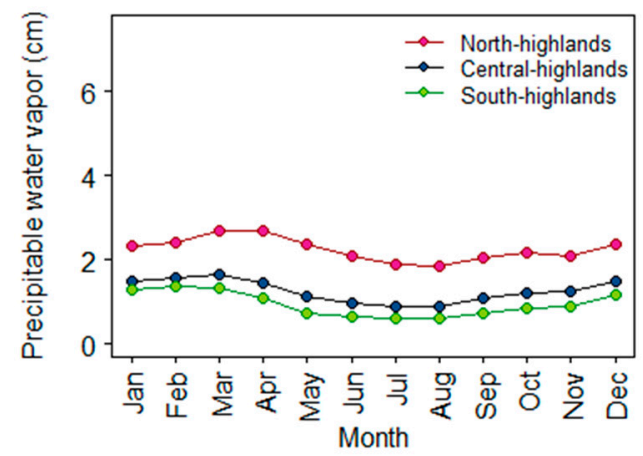

e) Monthly variation: Jungle

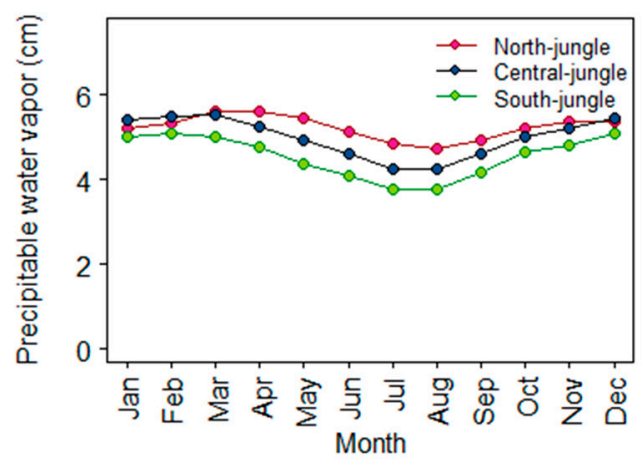

b) Standard deviation: Coast

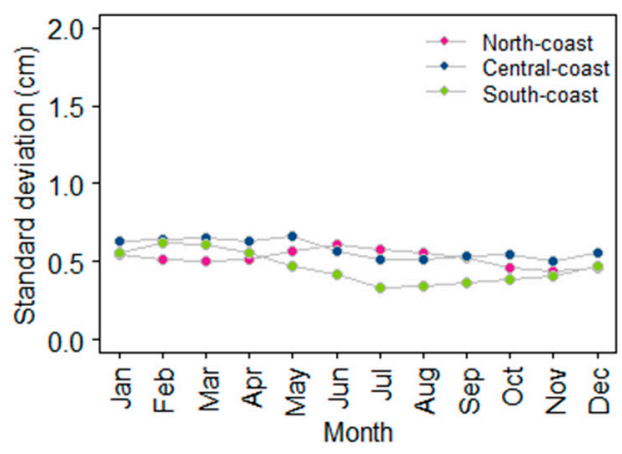

d) Standard deviation: Highlands

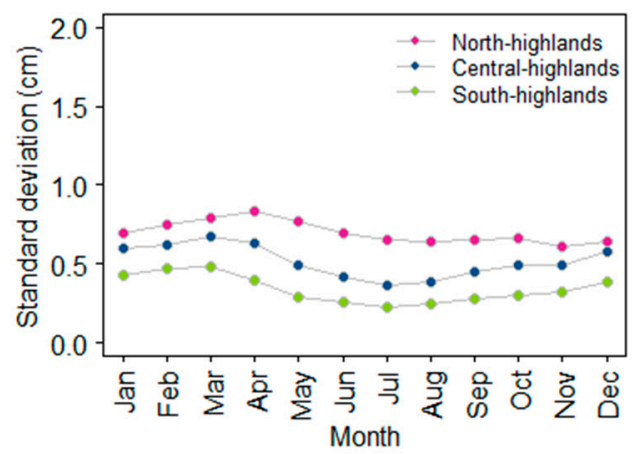

f) Standard deviation: Jungle

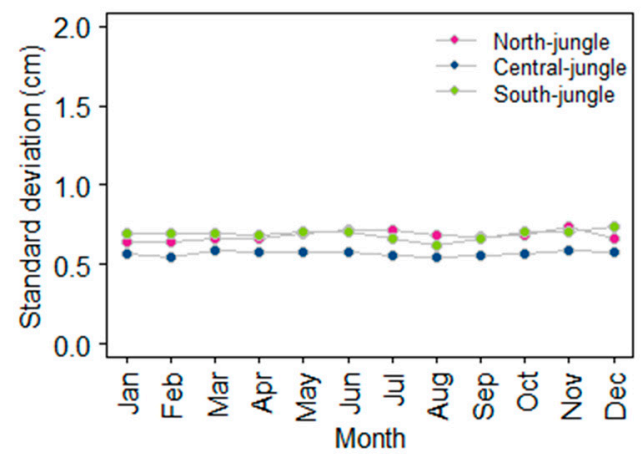

Figure 4. Analysis of PWV variations at monthly level (mean values and standard deviation) using MODIS PWV product (2000-2017): (a,b) for the Coast region, (c,d) for the Highlands region, and $(\mathbf{e}, \mathbf{f})$ for the Jungle region. 


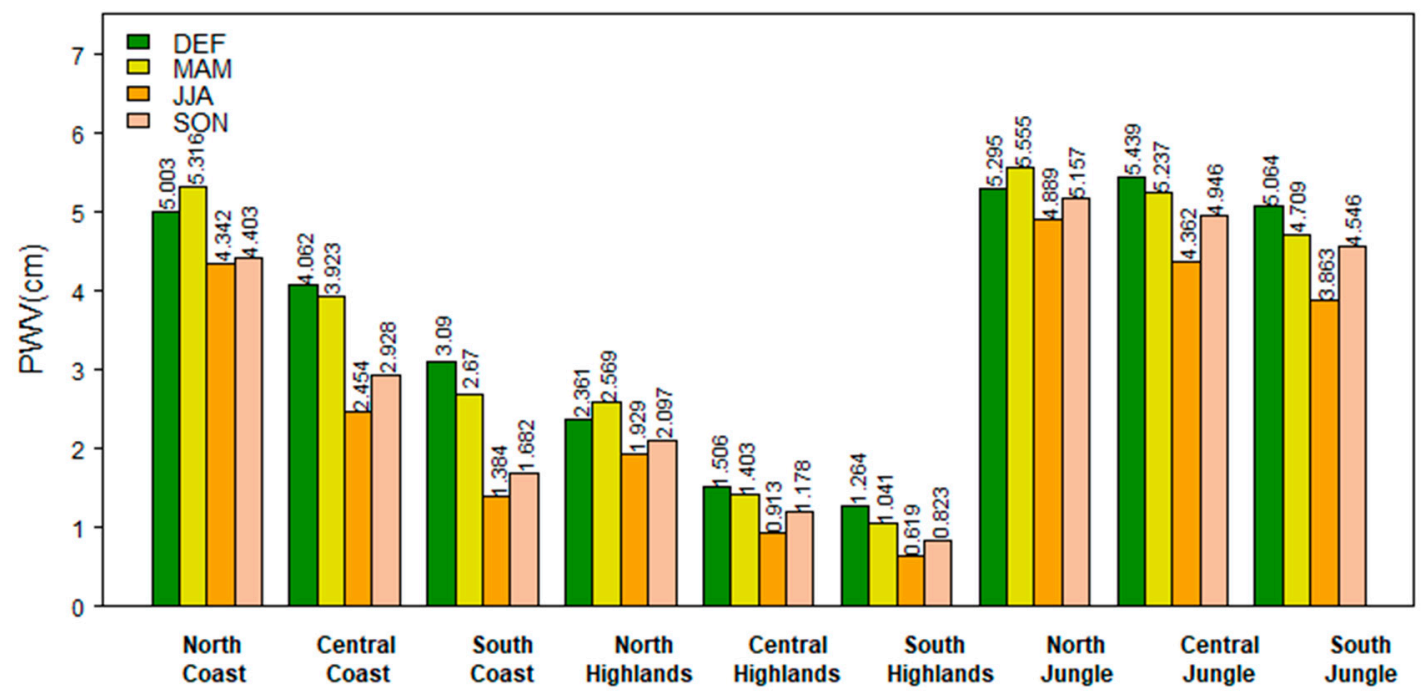

Figure 5. Seasonal variation of PWV obtained from MODIS product (2000-2017) for each sub-region.

a) DJF

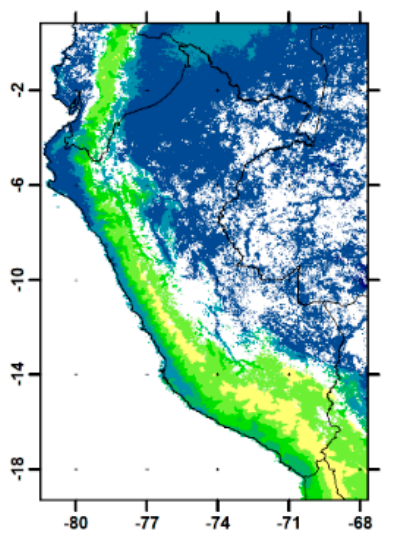

c) JJA

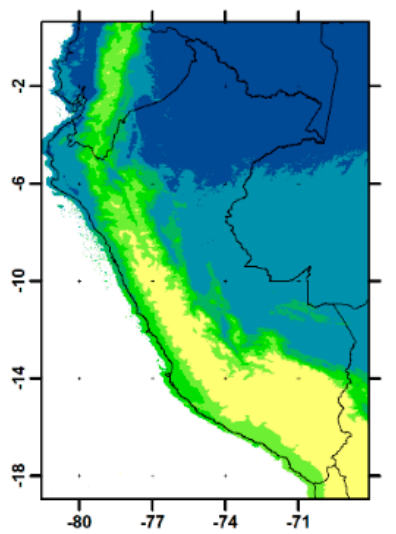

b) MAM

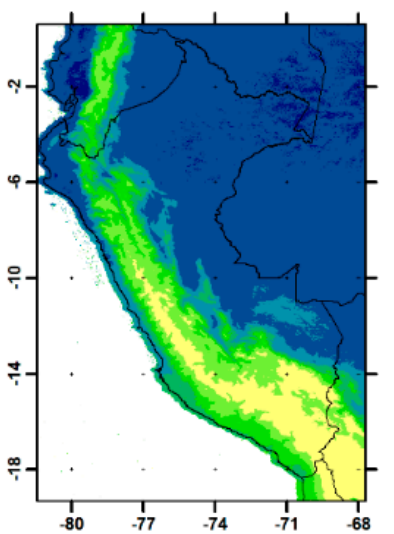

d) SON

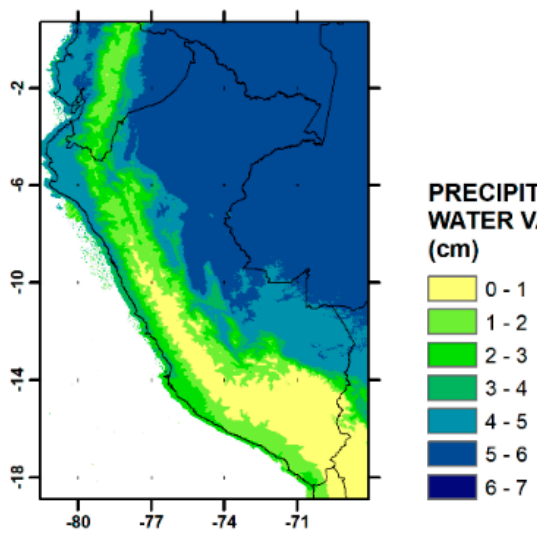

Figure 6. Spatial pattern of PWV over Peru for: (a) DJF, (b) MAM, (c) JJA and (d) SON seasons. Maps obtained from MODIS product. 

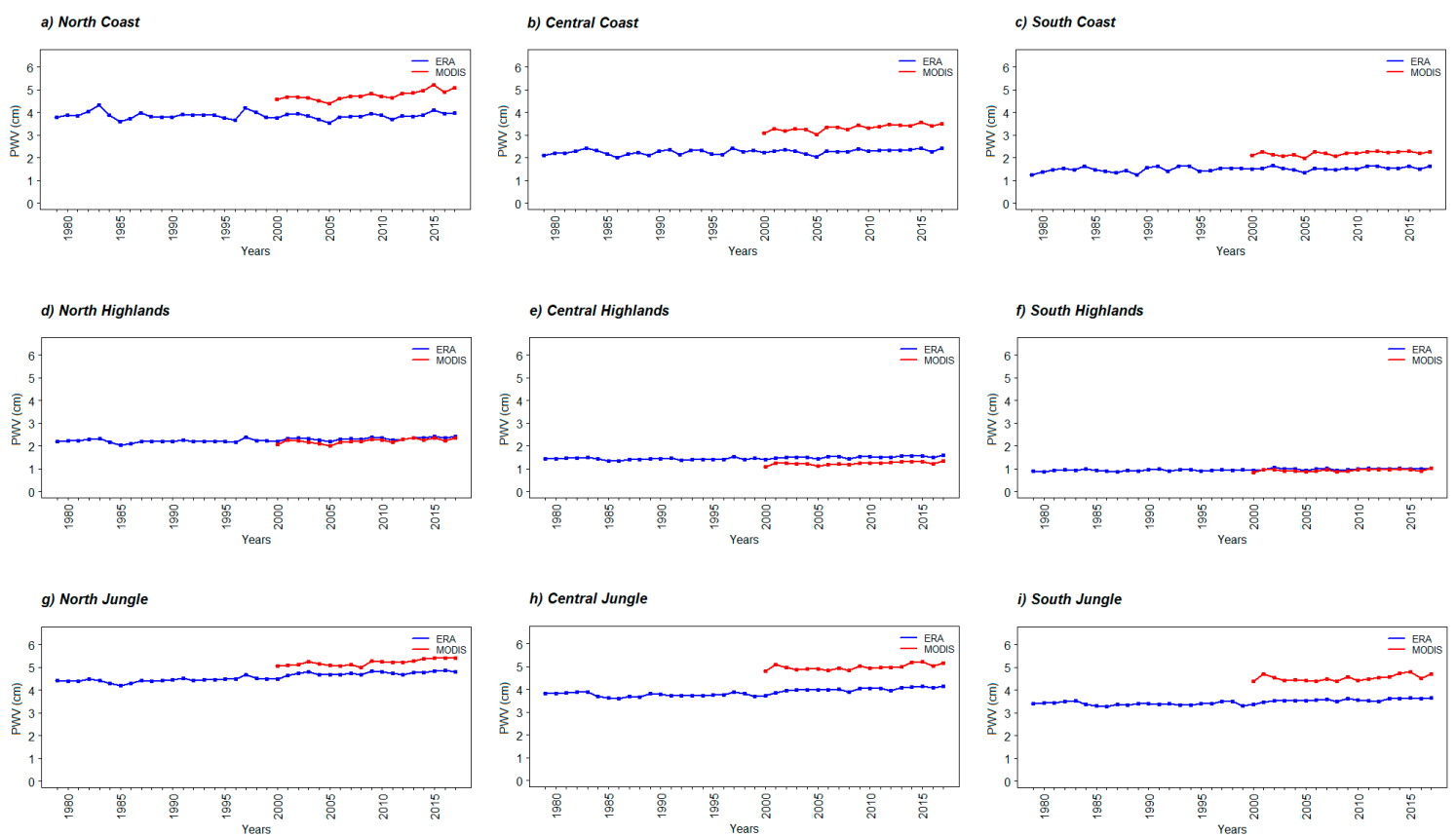

Figure 7. Multiannual variation of the PWV using MODIS and ERA-Interim datasets: (a-c) for the Coast region, (d-f) for the Highlands region, and ( $\mathbf{g}-\mathbf{i})$ for the Jungle region.
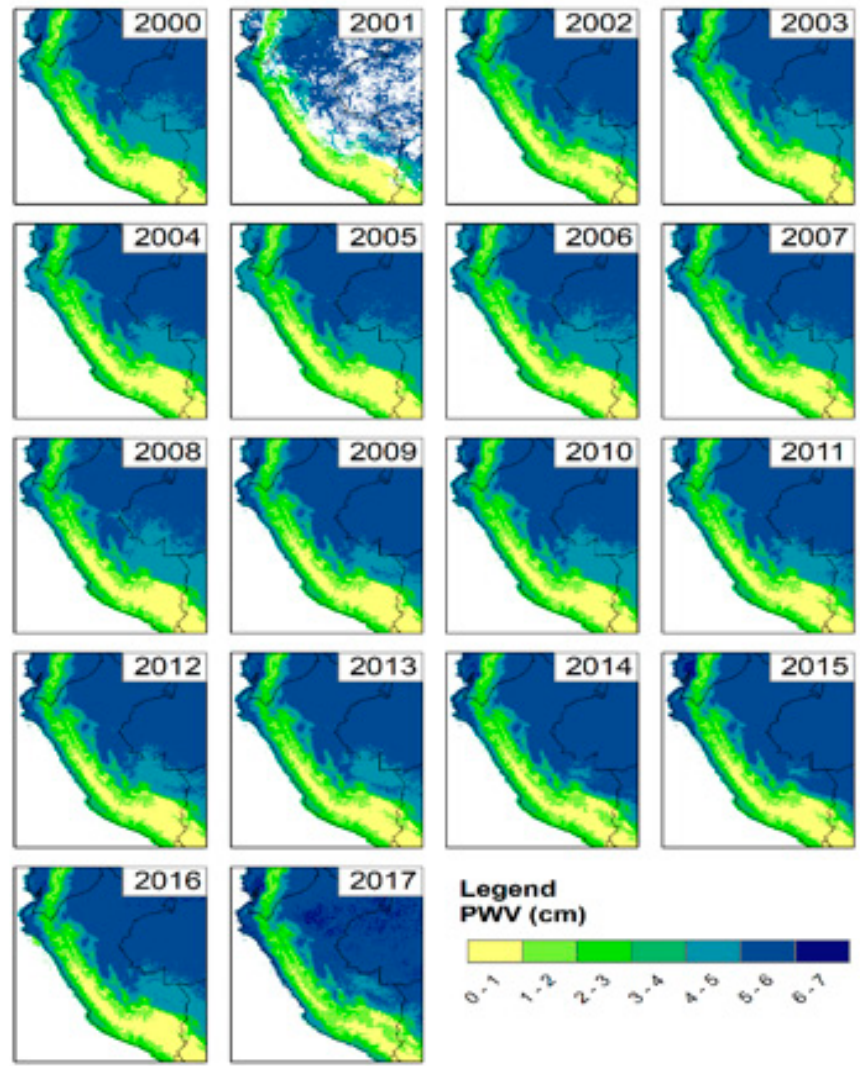

Figure 8. Spatial patterns of PWV over Peru at a yearly level (from 2000 to 2017) using MODIS product.

PWV seasonality was also investigated through box plots presented in Figure 9 for the nine study sub-regions. In agreement with results presented above, the highest PWV content was obtained during the austral summer months, and the lowest content during the austral winter months, with maximum and minimum peaks in March and July, respectively. The highest PWV variations (standard deviation) 
are observed in the jungle region (Figure $9 \mathrm{~g}-\mathrm{i}$ ). The outliers observed over the highland region in November and January are related to years 2000 and 2004.

a. North coast

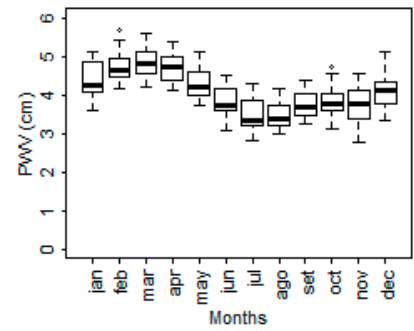

d. North highlands

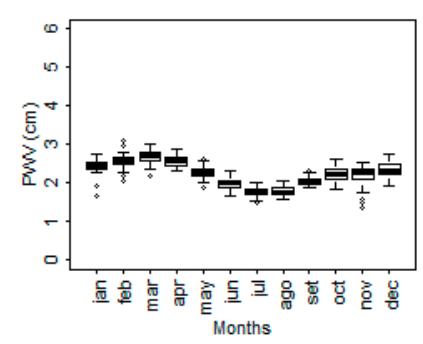

g. Northern jungle

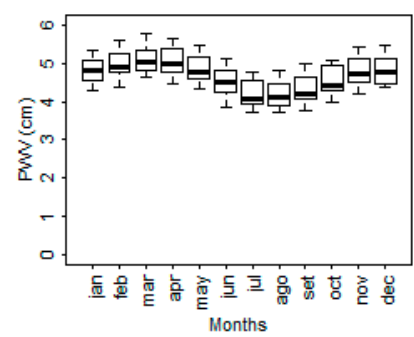

b. Central coast

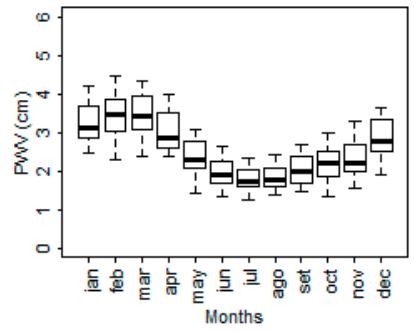

e. Central highlands

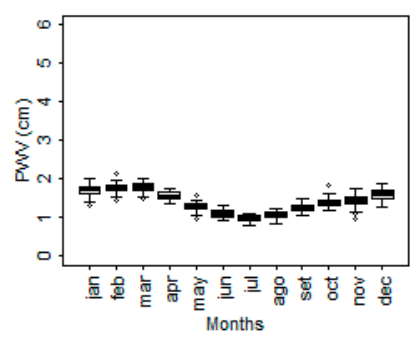

h. Central jungle

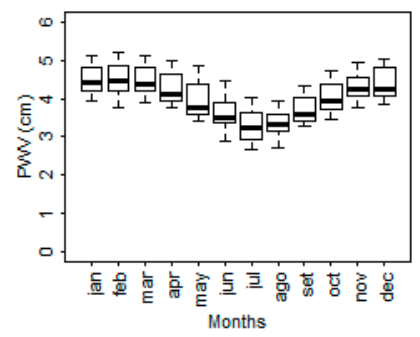

c. South coast

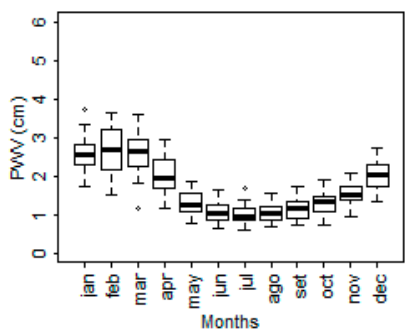

f. South highlands

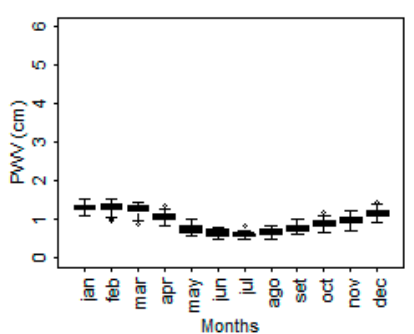

i. Southern jungle

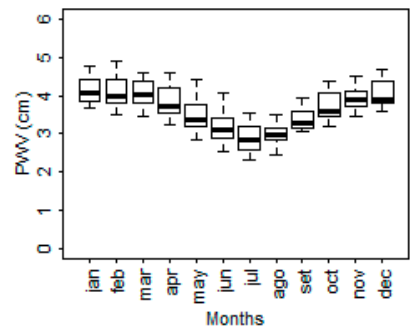

Figure 9. Boxplots of monthly PWV extracted from MODIS product for the different sub-regions: (a) North Coast, (b) Central Coast, (c) South Coast, (d) North Highlands, (e) Central Highlands, (f) South Highlands, (g) North Jungle, (h) Central Jungle, and (i) South Jungle. Boxplots include the first and third quartile (lower and upper limits of the box, respectively), the median (thick line inside the box), the maximum and minimum (whiskers), and outliers (points above or under the boxes) values.

\subsection{Trend Analysis}

Trend analysis was performed for the PWV time series extracted from MODIS (2000-2017) and ERA-Interim (1979-2017) products (Tables 5 and 6, respectively). PWV values were converted to quarterly anomalies (DJF, MAM, JJA and SON) prior to application of the Mann-Kendall test. Overall, the two datasets provide positive slopes for all seasons and sub-regions, except for the case of ERA-interim for the DJF and MAM seasons over the North Coast sub-region, and SON season for Central and South Coast sub-regions, with negative (but not statistically significant) values of the slope. Most of the positive values of slope are statistically significant for all sub-regions during DJF and JJA seasons, especially for the ERA-interim dataset which covers a longer period (Table 6). In this last case, also MAM and SON seasons show several statistically significant values of the slope, in contrast to the MODIS dataset which shows that most of the values for MAM and SON season are not statistically significant. According to the ERA-interim dataset, Highlands and Jungle regions typically show a significant increasing trend on PWV during all seasons, with the jungle region providing the highest 
values of slope for the SON season. Trends over the Coast sub-regions are not statistically significant in most cases, even with a decreasing trend in some cases.

Table 5. Results of the Mann-Kendall test applied to seasonal (DJF, MAM, JJA and SON) MODIS PWV anomalies for the nine sub-regions during the period 2000-2017. Values of tau coefficient, significance level $(p)$ and slope of the trend ( $\mathrm{cm} /$ year) are also given. Values of slope statistically significant $(p<0.05)$ are underlined.

\begin{tabular}{|c|c|c|c|c|c|c|c|c|c|c|c|c|}
\hline \multirow{2}{*}{ Region } & \multicolumn{3}{|c|}{$D J F$} & \multicolumn{3}{|c|}{$M A M$} & \multicolumn{3}{|c|}{$J J A$} & \multicolumn{3}{|c|}{ SON } \\
\hline & tau & $p$ & slope & tau & $p$ & slope & tau & $p$ & slope & tau & $p$ & slope \\
\hline N. Coast & 0.43 & 0.019 & 0.039 & 0.44 & 0.012 & 0.0322 & 0.62 & 0.0004 & 0.0299 & 0.29 & 0.0956 & 0.077 \\
\hline C. Coast & 0.53 & 0.003 & $\underline{0.028}$ & 0.36 & 0.041 & 0.0258 & 0.58 & 0.0009 & $\underline{0.0246}$ & 0.26 & 0.1501 & 0.075 \\
\hline S. Coast & 0.15 & 0.434 & $\overline{0.010}$ & 0.09 & 0.649 & $\overline{0.0088}$ & 0.33 & 0.0582 & $\overline{0.0135}$ & 0.20 & 0.2558 & 0.067 \\
\hline N. High. & 0.40 & 0.029 & $\underline{0.032}$ & 0.31 & 0.081 & 0.0179 & 0.41 & 0.0189 & $\underline{0.0165}$ & 0.07 & 0.7049 & 0.041 \\
\hline C. High. & 0.43 & 0.019 & 0.020 & 0.20 & 0.256 & 0.0157 & 0.45 & 0.0100 & $\overline{0.0090}$ & 0.14 & 0.4487 & 0.027 \\
\hline S. High. & 0.19 & 0.303 & 0.024 & 0.19 & 0.289 & 0.0155 & 0.24 & 0.1727 & $\overline{0.0086}$ & 0.02 & 0.9396 & 0.026 \\
\hline N. Jungle & 0.56 & 0.002 & 0.019 & 0.40 & 0.023 & 0.0118 & 0.36 & 0.0408 & 0.0150 & 0.54 & 0.0019 & 0.036 \\
\hline C. Jungle & 0.35 & 0.053 & $\overline{0.012}$ & 0.31 & 0.081 & $\overline{0.0059}$ & 0.22 & 0.2255 & $\overline{0.0065}$ & 0.10 & 0.5959 & $\overline{0.019}$ \\
\hline S. Jungle & 0.38 & 0.036 & $\underline{0.003}$ & 0.22 & 0.226 & 0.0033 & 0.15 & 0.4047 & 0.0044 & 0.09 & 0.6494 & 0.016 \\
\hline
\end{tabular}

Table 6. Same as Table 5, for ERA-Interim data and the period 1979-2017. Negative slopes are colored in red.

\begin{tabular}{|c|c|c|c|c|c|c|c|c|c|c|c|c|}
\hline \multirow{2}{*}{ Region } & \multicolumn{3}{|c|}{$D J F$} & \multicolumn{3}{|c|}{$M A M$} & \multicolumn{3}{|c|}{$J J A$} & \multicolumn{3}{|c|}{ SON } \\
\hline & tau & $p$ & slope & tau & $p$ & slope & tau & $p$ & slope & tau & $p$ & slope \\
\hline N. Coast & -0.11 & 0.333 & -0.004 & 0.04 & 0.7166 & -0.0004 & 0.2824 & 0.0119 & $\underline{0.004}$ & 0.24 & 0.0353 & $\underline{0.004}$ \\
\hline C. Coast & 0.13 & 0.255 & 0.002 & 0.19 & 0.0903 & 0.0039 & 0.2662 & 0.0177 & $\overline{0.004}$ & -0.03 & 0.7901 & $-\overline{0.0005}$ \\
\hline S. Coast & 0.26 & 0.021 & $\underline{0.008}$ & 0.21 & 0.0624 & 0.0051 & 0.1986 & 0.0773 & 0.003 & 0.018 & 0.8846 & -0.0004 \\
\hline N. High. & 0.28 & 0.011 & $\overline{0.015}$ & 0.42 & 0.0001 & $\underline{0.0125}$ & 0.4878 & 0.0000 & $\underline{0.014}$ & 0.24 & 0.0313 & $\underline{0.004}$ \\
\hline C. High. & 0.47 & 0.000 & $\overline{0.012}$ & 0.47 & 0.0000 & $\overline{0.0114}$ & 0.3041 & 0.0067 & $\overline{0.008}$ & 0.27 & 0.0145 & $\overline{0.003}$ \\
\hline S. High. & 0.55 & 0.000 & 0.009 & 0.35 & 0.0020 & 0.0076 & 0.2122 & 0.0591 & 0.005 & 0.10 & 0.3970 & 0.0007 \\
\hline N. Jungle & 0.67 & 0.000 & $\overline{0.004}$ & 0.59 & 0.0000 & $\overline{0.0057}$ & 0.6905 & 0.0000 & $\underline{0.006}$ & 0.63 & 0.0000 & $\underline{0.0149}$ \\
\hline C. Jungle & 0.62 & 0.000 & 0.005 & 0.52 & 0.0000 & $\underline{0.0050}$ & 0.3851 & 0.0006 & $\underline{0.003}$ & 0.52 & 0.0000 & 0.0092 \\
\hline S. Jungle & 0.55 & 0.000 & $\overline{0.005}$ & 0.46 & 0.0000 & $\overline{\underline{0.0037}}$ & 0.3095 & 0.0058 & $\underline{0.0015}$ & 0.46 & 0.0000 & $\overline{0.0058}$ \\
\hline
\end{tabular}

In order to deepen the study of the trends, the ERA-interim dataset was split into two subperiods of time, 1979-1999 and 2000-2017. This allows the comparison of MODIS and ERA-interim for the same period 2000-2017, and also to assess if trends in the last two decades show a higher increase on PWV than the two previous decades (results not shown in the paper). This trend analysis showed that slope values were higher for the period 2000-2017 than the period 1979-1999, especially for the jungle sub-regions and seasons JJA and SON, thus suggesting an intensification on the increase of PWV in the latest decades. Slope values obtained from MODIS and ERA-interim for the same period (2000-2017) are consistent in some cases, but huge discrepancies were observed in other cases, such as the SON season over the coast sub-regions. Surprisingly, the consistency (when slope values are compared) between MODIS and ERA-interim for the same period (2000-2017) was similar than the consistency between MODIS (2000-2017) and ERA-interim for the whole period (1979-2017).

\subsection{Validation against Radiosonde Data}

The analysis of results was completed with the validation of PWV values extracted from MODIS and ERA-interim against PWV extracted from radiosonde data (Figure 10). It should be noted that this validation should be considered with caution because of the coarse resolution of PWV from MODIS $(1 \mathrm{~km})$ and overall for the PWV extracted from ERA-interim (approximately $79 \mathrm{~km}$ ), added to the shift between the MODIS overpass (between 1400 UTC and 1600 UTC) and the launching time of the radiosonde (1200 UTC). Validation results are presented for the MOD05 PWV product (Terra platform) because the overpass time for this product is closer to the radiosonde time than the MYD05 product. 
The results of the validation show a good performance of both PWV products. However, results for the MOD05 PWV product were better than results obtained for the ERA-interim PWV product, with a Root Mean Square Error (RMSE) $<0.6 \mathrm{~cm}\left(\right.$ and $\left.\mathrm{R}^{2}=0.71\right)$ for MODIS, and RMSE $=0.9 \mathrm{~cm}\left(\mathrm{R}^{2}=0.61\right)$ for ERA-interim. The bias for the MOD05 product is slightly positive $(0.24 \mathrm{~cm})$, whereas the bias for ERA-interim has a higher magnitude and is negative $(-0.68 \mathrm{~cm})$, thus indicating an underestimation of this last product. As stated before, the spatial resolution of ERA-interim may explain the worse results in the validation. For example, the radiosonde stations "Lima/Callao" and "Las Palmas" (see Table 1) are both within one pixel of ERA-interim.
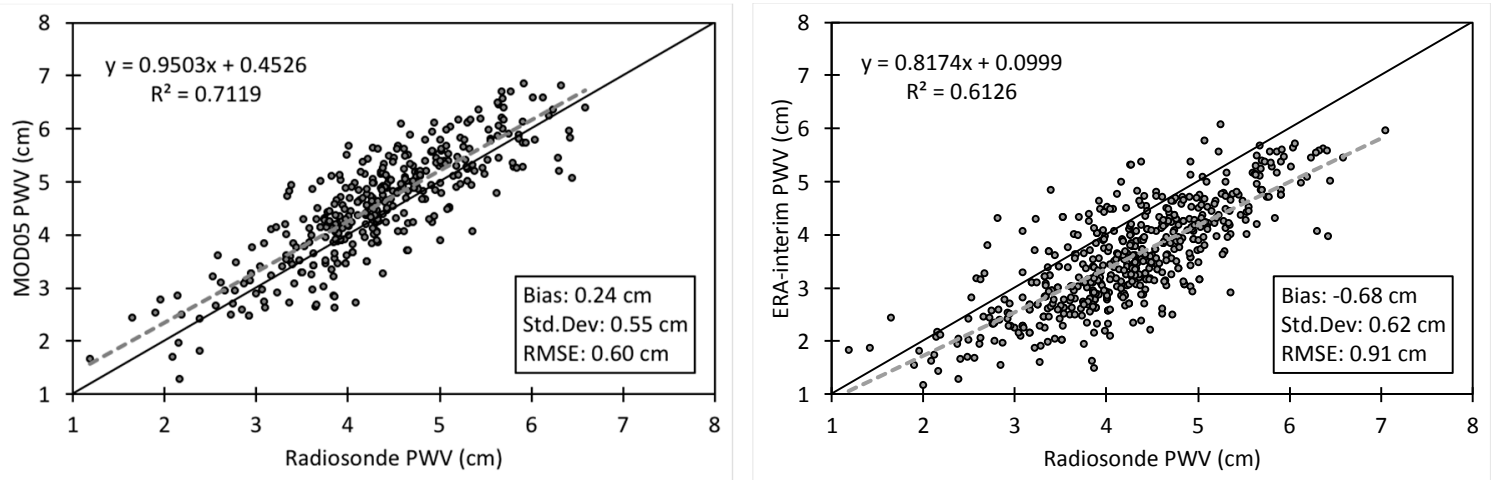

Figure 10. Comparison of PWV values extracted from (a) MODIS (MOD05) and (b) ERA-interim products against values obtained from in situ radiosonde stations (as described in Table 1). Slope, intercept, and coefficient of determination $\left(\mathrm{R}^{2}\right)$ are also included, as well as basic statistics such as bias (PWV product minus radiosonde), standard deviation and Root Mean Square Error (RMSE).

The continuous line indicates the line 1:1, and the dashed line indicates the linear fit.

\section{Conclusions}

This study provided one of the first detailed analyses of spatio-temporal variations of PWV over the Peruvian regions classified as coast, highlands and jungle, which in turn were split into north, central and south sub-regions. Both satellite (MODIS) and reanalysis (ERA-interim) data were used to address this research. As expected, the spatial and temporal patterns of PWV were heterogeneous among all the sub-regions.

The spatial analysis showed a spatial dependence of the PWV in the Northeast and East directions, mainly. Analysis of sill and range values evidenced that regions such as the northern jungle and the southern jungle have a very high spatial variability. PWV content also showed a marked seasonal component, with maximum values during austral summer and minimum values during austral winter. In terms of regional analysis, the highest values of PWV were obtained over the jungle region and northern coast region, with maximum PWV values of around $6 \mathrm{~cm}$ during summer and minimum PWV values of around $4 \mathrm{~cm}$ during winter. The lowest PWV values were obtained over the Southern Highland region because of its characteristic geographical factors such as latitude and altitude.

Overall, the trend analysis suggested an increase of PWV in all the sub-regions characterized by a high PWV content, such as the north coast sub-region and all the jungle sub-regions. The increase on PWV was more significant for the DJF, MAM and JJA seasons. These results may be consistent with a global warming scenario and repeated occurrence of El Niño events, although a dedicated analysis is required to assess the impact of the different climatic events. Also, significant discrepancies were found between MODIS and ERA-interim trend values, which requires further research.

Finally, MODIS and ERA-interim PWV products were validated against radionsonde data over a limited number of Peruvian radionsonde stations. MODIS MOD05 product provided better results than ERA-interim, with a RMSE $<0.6 \mathrm{~cm}$, which is consistent with previous validations of this product (e.g., $[11,42]$ ). ERA-interim also provided satisfactory results $($ RMSE $=0.9 \mathrm{~cm}$ ), but the validation of 
this product is jeopardized by its low spatial resolution $(79 \mathrm{~km})$. The new release of ECMWF reanalysis ERA5 may overcome this limitation because of its finer grid.

Author Contributions: K.L.C. and J.J.P. conceived the study, processed the data, and drafted all the figures. J.C.J. contributed to the reanalysis processing, analysis of results, and wrote the paper.

Funding: This research received no external funding.

Acknowledgments: We thank MODIS project, ECMWF and University of Wyoming for open access to the datasets (MOD05/MYD05, ERA-interim and radiosonde data, respectively). We also thank the comments and suggestions from two anonymous reviewers, which helped us to improve the manuscript.

Conflicts of Interest: The authors declare no conflict of interest.

\section{References}

1. Al-Mashagbah, A.; Al-Farajat, M. Assessment of Spatial and Temporal Variability of Rainfall Data Using Kriging, Mann Kendall Test and the Sen's Slope Estimates in Jordan from 1980 to 2007. Res. J. Environ. Earth Sci. 2013, 5, 611-618.

2. Arraut, J.M.; Satyamurty, P. Precipitation and water vapor transporting the Southern Hemisphere with emphasis on the South American region. J. Appl. Meteorol. Climatol. 2009, 48, 1902-1912. [CrossRef]

3. Barnes, W.L.; Pagano, T.S.; Salomonson, V.V. Prelaunch Characteristics of the Moderate Resolution Imaging Spectroradiometer (MODIS) on EOS-AM1. IEEE Trans. Geosci. Remote Sens. 1998, 36, 1088-1100. [CrossRef]

4. Berrisford, P.; Dee, D.; Fielding, K.; Fuentes, M.; Kallberg, P.; Kobayashi, S.; Uppala, S. The ERA-Interim Archive; ERA Report Series 1; ECMWF: Reading, UK, 2009; 16p.

5. Berrisford, P.; Kallberg, P.; Kobayashi, S.; Dee, D.P.; Uppala, S.M.; Simmons, A.J.; Poli, P. Atmospheric Conservation Properties in ERA-Interim; ERA Report Series; ECMWF: Reading, UK, 2011.

6. Burrough, P.A. Principles of Geographical Information Systems for Land Resources Assessment; Clarendon Press: Oxford, UK, 1986; 193p.

7. Carvalho, J.R.P.; Vieira, S.R.; Grego, C.R. Comparação de métodos para ajuste de modelos de semivariograma da precipitação pluvial anual. Revista Brasileira de Engenharia Agrícola e Ambiental 2009, 13, 443-448. [CrossRef]

8. Chang, L.; Gao, G.; Jin, S.; He, X.; Xiao, R.; Guo, L. Calibration and evaluation of precipitable water vapor from MODIS infrared observations at night. IEEE Trans. Geosci. Remote Sens. 2015, 53, 2612-2620. [CrossRef]

9. Chebana, F.; Ouarda, T.B.M.J.; Duong, T.C. Testing for multivariate trends in hydrologic frequency analysis. J. Hydrol. 2013, 486, 519-530. [CrossRef]

10. Clark, I. Regularization of a semivariogram. Comput. Geosci. 1977, 3, 341-346. [CrossRef]

11. Cressie, N.A.C. Statistics for Spatial Data; John Wiley \& Sons: New York, NY, USA, 1991; 900p.

12. Dee, D.P.; Uppala, S.M.; Simmons, A.J.; Berrisford, P.; Poli, P.; Kobayashi, S.; Andrae, U.; Balmaseda, M.A.; Balsamo, G.; Bauer, P.; et al. The ERA-Interim reanalysis: Configuration and performance of the data assimilation system. Q. J. R. Meteorol. Soc. 2011, 137, 553-597. [CrossRef]

13. Espinoza, J.C.; Ronchail, J.; Guyot, J.L.; Cochonneau, G.; Naziano, F.; Lavado, W.; Oliveira, E.; Pombosa, R.; Vauchel, P. Spatio-temporal rainfall variability in the Amazon basin countries (Brazil, Peru, Bolivia, Colombia, and Ecuador). Int. J. Climatol. 2009, 29, 1574-1594. [CrossRef]

14. Fernández, L.I.; Meza, A.M.; Natali, M.P. Determinación del contenido de vapor de agua precipitable (PWV) a partir de mediciones GPS: Primeros resultados en Argentina. Geoacta 2009, 34, 35-57.

15. Gao, B.C.; Kaufman, Y.J. The MODIS Near-IR Water Vapor Algorithm. 1998. Available online: https: //modis-atmos.gsfc.nasa.gov/_docs/atbd_mod03.pdf (accessed on 7 April 2019).

16. Gao, B.C.; Kaufman, Y.J. Water vapor retrievals using Moderate Resolution Imaging Spectroradiometer (MODIS) near-infrared channels. J. Geophys. Res. 2003, 108, 4389. [CrossRef]

17. Liang, H.; Cao, Y.; Wan, X.; Xu, Z.; Wang, H.; Hu, H. Meteorological applications of precipitable water vapor measurements retrieved by the national GNSS network of China. Geod. Geodyn. 2015, 6, 135-142. [CrossRef]

18. Journel, A.G.; Froidevaux, R. Anisotropic Hole-Effect Modeling. Math. Geol. 1982, 14, 217-247. [CrossRef]

19. Kaufman, Y.J.; Gao, B.C. Remote sensing of water vapor in the near IR from EOS/MODIS. IEEE Trans. Geosci. Remote Sens. 1992, 30, 871-884. [CrossRef] 
20. Kendall, M.G. Rank Correlation Methods, 4th ed.; Charles Griffin: London, UK, 1975.

21. King, M.D.; Kaufman, Y.J.; Menzel, W.P.; Tanré, D. Remote sensing of cloud, aerosol, and water vapor properties from the Moderate Resolution Imaging Spectrometer (MODIS). IEEE Trans. Geosci. Remote Sens. 1992, 30, 2-27. [CrossRef]

22. King, M.D.; Herring, D.D.; Diner, D.J. The Earth Observing System: A Space-based Program for Assessing Mankind's Impact on the Global Environment. Opt. Photonics News 1995, 6, 34-39. [CrossRef]

23. King, M.D.; Menzel, W.P.; Kaufman, Y.J.; Tanré, D.; Gao, B.C.; Platnick, S.; Ackerman, S.A.; Remer, L.A.; Pincus, R.; Hubanks, P.A. Cloud and aerosol properties, precipitable water, and profiles of temperature and water vapor from MODIS. IEEE Trans. Geosci. Remote Sens. 2003, 41, 442-458. [CrossRef]

24. Lara, C.; Miranda, M.; Montecino, V.; Iriarte, J.L. Chlorophyll-a MODIS mesoscale variability in the Inner Sea of Chiloé, Patagonia, Chile (41-43ㅇ): Patches and Gradients? Revista de Biología Marina y Oceanografía 2010, 45, 217-225. [CrossRef]

25. Longobardi, A.; Villani, P. Trend analysis of annual and seasonal rainfall time series in the Mediterranean area. Int. J. Climatol. 2010, 30, 1538-1546. [CrossRef]

26. L'Heureux, M.L.; Takahashi, K.; Watkins, A.B.; Barnston, A.G.; Becker, E.J.; Di Liberto, T.E.; Gamble, F.; Gottschalck, J.; Halpert, M.S.; Huang, B.; et al. Observing and predicting the 2015-16 El Niño. Bull. Am. Meteorol. Soc. 2017, 98, 1363-1382. [CrossRef]

27. Mann, H.B. Non-parametric Test against Trend. Econometrica 1945, 13, 245-259. [CrossRef]

28. Marengo, J.A.; Nobre, C.A.; Tomasella, J.; Oyama, M.D.; Oliveira, G.S.; Oliveira, R.; Camargo, H.; Alves, L.M. The dought of Amazonia in 2005. J. Clim. 2008, 21, 495-516. [CrossRef]

29. Matheron, G. Le Krigeage Universei; No. 1.; Cahiers de Centre de Morphologie Mathematique: Fontainbleau, France, 1969.

30. Mattar, C.; Sobrino, J.A.; Julien, Y.; Morales, L. Trends in column integrated water vapour over Europe from 1973 to 2003. Int. J. Climatol. 2010, 31, 1749-1757. [CrossRef]

31. Moreira, J.G.V.; Naghettini, M. Detecção de Tendências Monotônicas Temporais e Relação com Erros dos Tipos I e II: Estudo de Caso em Séries de Precipitações Diárias Máximas Anuais do Estado do Acre. Revista Brasileira de Meteorologia 2016, 31, 394-402. [CrossRef]

32. Ning, T.; Wickert, J.; Deng, Z.; Heise, S.; Dick, G.; Vey, S.; Schöne, T. Homogenized time series of the atmospheric water vapor content obtained from the GNSS reprocessed data. J. Clim. 2016, 29, 2443-2456. [CrossRef]

33. Platnick, S.; King, M.D.; Ackerman, S.A.; Menzel, W.P.; Baum, B.A.; Riédi, J.C.; Frey, R.A. The MODIS cloud products: Algorithms and examples from Terra. IEEE Trans. Geosci. Remote Sens. 2003, 41, 459-473. [CrossRef]

34. Salati, E.; Marques, J.; Molion, L.C.B. Origem e distribuição das chuvas na Amazônia. Interciência 1978, 3, 200-206.

35. Salomonson, V.V.; Barnes, W.L.; Maymon, P.W.; Montgomery, H.E.; Ostrow, H. MODIS: Advanced facility instrument for studies of the Earth as a system. IEEE Trans. Geosci. Remote Sens. 1989, 27, 145-153. [CrossRef]

36. Simmons, A.; Uppala, S.; Dee, D.; Kobayashi, S. ERA-Interim: New ECMWF reanalysis products from 1989 onwards. ECMWF Newsl. 2007, 110, 25-35.

37. Sobrino, J.A.; El Kharraz, J.; Li, Z.-L. Surface temperature and water vapour retrieval from MODIS data. Int. J. Remote Sens. 2003, 24, 5161-5182. [CrossRef]

38. Russ, J.C. The Image Processing Handbook; CRC Press-IEEE Press: Piscataway, NJ, USA, 1998.

39. Wang, H.; Wei, M.; Li, G.; Zhou, S.; Zeng, Q. Analysis of precipitable water vapor from GPS measurements in Chengdu region: Distribution and evolution characteristics in autumn. Adv. Space Res. 2013, 52, 656-667. [CrossRef]

40. Wang, Y.; Yang, K.; Pan, Z.; Qin, J.; Chen, D.; Lin, C.; Chen, Y.; Zhu, L.; Tang, W.; Han, M.; et al. Evaluation of precipitable water vapor from four satellite products and four reanalysis datasets against GPS measurements on the southern Tibetan Plateau. J. Clim. 2017, 30, 5699-5713. [CrossRef] 
41. Wilks, D.S. Statistical Methods in the Atmospheric Sciences; Elsevier/Academic Press: Amsterdam, The Netherlands, 2011; 699p.

42. Woodcock, C.E.; Strahler, A.H.; Jupp, D.L.B. The use of variograms in remote sensing: I. Scene models and simulated images. Remote Sens. Environ. 1988, 25, 323-348. [CrossRef] 